\title{
Marka Özgünlüğünün Marka İmajı ve Marka Tercihindeki İlişkisinde Marka Güveninin Aracılık Rolï${ }^{1}$
}

\author{
DOI: 10.26466/opus.741062
}

\author{
Kazım Dağ $\breve{g}^{*}$ Yakup Durmaz** \\ *Doktora Öğrencisi, Hasan Kalyoncu Üniversitesi, İşletme Anabilim Dalı, Gaziantep/Turkiye \\ E-Posta: kzmdgnrhk@gmail.com \\ ORCID: $0000-0003-0643-6932$ \\ *Doç. Dr., Hasan Kalyoncu Üni., İ̈BF., İşletme Bölümü, Gaziantep/Turkiye \\ E-Posta: yakupdu@hotmail.com \\ ORCID: $\underline{0000-0003-0332-4185}$
}

\begin{abstract}
Öz
Araştırmanın amacı, günümüz finansal krizlerinde ayakta kalmayı sağlayacak bir unsur olan marka özgünlüğünün; marka imajına ve marka tercihine olan etkisinin tespit edilmesi, ayrıca marka güveninin, marka imajı ve marka tercihine etkisinde aracı etkiye sahip olup olmadığııın ortaya konulmasıdır. Bu amaçla marka özgünlü̈̆̈̈nün alt boyutları olan erdem, bağlantl, gerçeklik, estetiklik, kontrtol ve orjinallik ile marka imajı ve marka tercihi ilişkisi araştırılmış, marka güveninin marka imajı ve marka tercihi üzerindeki aracı etkisi model ışı̆̆ında incelenmiştir. Yapılan pilot uygulamada; marka özgünlüğ̈̈, marka imajı, marka tercihi ve marka güveni ölçeklerinin toplam varyansı açılama oranlarını ve Kaiser-MeyerOlkin (KMO) testlerinin örneklem yeterlilik değerinin faktör analizi için yeterli olduğu belirlenmiştir. Araştırmanın çalı̧̧ma grubunu beyaz eşya kullanan, satın alan (816) nihayi tüketici oluşturmaktadır. Toplanan veriler SPSS ve AMOS programlarıla analiz edilmiştir. Analiz sonuçlarına göre marka özgünlüğ̈̈nün; marka imajı ve marka tercihine olumlu yönde anlaml bir etkisinin olduğu tespit edilmiştir. Analizlere göre marka güveninin aracılık etkisinin olduğu sonucuna ulaşılmış ve aracilı etkisi Sobel testi ile doğrulanmıştır.
\end{abstract}

Anahtar Kelimeler: Marka özgünlü̆̈̈̈, marka imajı, marka güveni, marka tercihi.

\footnotetext{
${ }^{1}$ Bu çalışma, Hasan Kalyoncu Üniversitesi Sosyal Bilimler Enstitüsü tarafından yürütülmekte olan doktora tezinden türetilmiştir.
} 


\title{
Mediation Role of Brand Trust in the Relationship of Brand Authenticity in Brand Image and Brand Preference
}

\begin{abstract}
The aim of the research is to determine the brand authenticity, which is a factor that will ensure survival in today's financial crises; determining the effect on the brand image and brand preference, and also revealing whether the brand trust has an intermediary effect on the brand image and brand preference. For this purpose, the relationship between brand image and brand preference with virtue, connection, reality, aesthetics, control and originality, which are sub-dimensions of brand authenticity, was investigated, and the mediating effect of brand trust on brand image and brand preference was examined in the light of the model. In the pilot study conducted; It was determined that the total variance explanation ratios of brand authenticity, brand image, brand preference and brand trust scales and the sampling adequacy value of Kaiser-Meyer-Olkin (KMO) tests were sufficient for factor analysis. The working group of the research is the end consumer who uses and buys (816) white goods. The collected data were analyzed with SPSS and AMOS programs. According to the analysis results, brand originality; It has been determined that it has a significant positive effect on brand image and brand preference. According to the analysis, it was concluded that brand trust has an intermediary effect and the mediation effect was confirmed by the Sobel test.
\end{abstract}

Keywords: Brand authenticity, brand image, brand trust, brand preference. 


\section{Giriş}

Giderek artan bir öneme sahip olan marka özgünlüğü; sayısız işletmenin günümüz koşullarında ayakta kalabilmek ve rekabetçi konumunu güçlendirip kendisini diğer markalardan ayırması açısından önemli bir yer tutmaktadır. Marka özgünlügünün diğer bir çok pazarlama kavramı ile ele alınarak çıtılarının işletmeler açısından değerlendirilmesinin önem arz ettiği değerlendirilmektedir. Pazarlama yöneticileri daha güçlü markalar yaratmak istediklerinde; özgünlük, marka kimliğinin önemli bir boyutu haline geldi (Alexander, 2009, s. 551). Geniş anlamda hakiki, gerçek ve doğruluk ifadelerine atıf yapan özgünlük, son yıllarda pazarlama yazınında sıklıkla kullanılan kavramlardan biri haline gelmiştir (Arnould ve Price, 2000, s. 142). Birçok firmanın ürünlerini diğer markalardan ayırmak için çaba harcadıkları görülmektedir. Ancak özgün markaların, diğer markalarla kıyaslandığında tüketici tarafından daha çok arzu edilen markalar olduğunu söylemek mümkündür (Brown vd., 2003, s. 20). Günümüz tüketim dünyasında özgünlük konusundaki bu arzu, fiyat ve ürün uygunluğu gibi önemli tüketim faktörlerinin dahi önüne geçebilmektedir.

Özgünlük, son on yılda artan ilgiyle postmodern markalaşmanın merkezi bir bileşeni haline gelen bir olgudur. Pazarlama akademisyenleri, tüketiciler arasındaki bu özgünlük talebini fark etmiş ve lüks şaraplar (Beverland, 2005b, 2006), gida (Beer, 2008), turizm (Grayson ve Martinec, 2004; Wang, 1999), tüketim alt kültürleri (Leigh vd., 2006), reality şovları (Rose ve Wood, 2005), reklamlar (Beverland vd., 2008) ve retro markalar (Brown vd., 2003) gibi birçok farklı alanda araştırmalar yapmışlardır. Sonuç olarak, artan özgünlük talebine uymak için markalar bu fenomeni iletişim stratejilerinin bir parçası olarak kullanmaya başladılar. Markaları içinde özgünlük yaratabilen organizasyonlar, kendilerini farklılaştırma ve rekabet avantajı kazanma şansına sahip olduğu belirtilmiştir (Gilmore ve Pine, 2007). Bu fırsat, marka özgünlügünün doğasını ve temel boyutlarını anlamada artan bir ilgi ve alaka düzeyi sağlamaktadır (Lindum ve Thomsen, 2019, s. 2). Sunulan özgünlük deneyimi, tutarlı bir şekilde büyüyebilmek için gereklidir (Durmaz ve Dağ, 2018, s. 490).

Tüm bu durumlar göz önüne alındığında marka özgünlügünün işletmeler açısından önemini ortaya koymak, marka imajı ve tercihini nasıl etkilediğini belirlemek ve marka güveninin aracılık rolünün olup olmadığını 
bilmek ve bu durumu ölçmek önemli bir problemdir. Araştırmada marka özgünlüğü unsurlarının marka imajı ve tercihine etki edip etmediğini ortaya koyulacak, ayrıca bu unsurların marka güvenine olabilecek etkisinde marka özgünlügünün ve marka imajı ve tercihinde aracı bir etkiye sahip olup olmadığı tespit edilecektir.

\section{Kavramsal Çerçeve}

\section{Marka Özgünlüğ̈̈}

Özgünlük kavramı, tarihsel olarak, "orijinaline uygun olarak kabul edilebilir, güvenilir, hayali, yanlış veya taklit değil" anlamına gelen Latince "authenticus" kelimesinden kaynaklanmaktadır (Cappannelli ve Cappannelli, 2004). Muñoz vd., (2006) bu terim geleneksel olarak doğal, dürüst, köklü ve insan olmanın bir ifadesi olarak kullanılmıştır ve günümüzde özgünlüğün genel tanımı orijinal, gerçek, geleneksel ve gerçek olmakla ilgilidir (Lindum ve Thomsen, 2019, s. 17). Günümüzde özgünlük, bir şeyin gerçekliğini veya gerçeğini açıklamak için yaygın olarak kullanılmaktadır (Lu vd., 2015).

Ancak söz konusu pazarlama literatürüne gelince, yaygın olarak kabul edilebilir bir özgünlük tanımı bulunmamaktadır. Farklı yazarlar, özgünlük anlamını, farklı ilişkiler ve işaretler kullanarak, doğrulukla ve gelenekle kavramsallaştırmaya çalışmışlardır. Dahası, araştırmacılar özgünlügü, kültürel, kişisel ya da pozitif değer gibi orijinallik ile ilişkilendirilen diğer yönleri ile tanımlamaya çalışmışlardır.. Ayrıca, orijinallik, "teklik", "kültürel veya geleneksel değerler", "üretim sürecinin özellikleri", kalite taahhütleri, yer ilişkisi", üretim "ve"gerçek " ile ilişkilendirerek tanımlamışlardır (Assiouras vd., 2015, s. 539). Durum böyle iken marka özgünlügünü tanımlamak da zorlaşmakta ve kavramsallaştırılmasında tutarsızlıklar taşımaktadır.

Marka özgünlüğü, markaların rekabetçi kalmasına yardımcı olmada yararlı olabileceğinden, literatürde daha fazla ilgi gören nispeten yeni bir marka kavramıdır (Wymer ve Akbar, 2017, s. 360) Marka özgünlüğü, iç organizasyon, diş tüketiciler ve diğer paydaşlar arasındaki sosyal müzakereler yoluyla zaman içinde değişebilen dinamik ve akıcı bir yapı olarak algılanmaktadır (Leigh vd., 2006). Bununla birlikte, marka özgünlüğünün yapısı oldukça karmaşıktır ve kavramsallaştırılmasında ve tanımlanmasında büyük tutarsızlıklar vardır (Portal vd., 2018, s. 2). 
Bruhn vd., (2012) marka özgünlügünün sadece markanın doğal nitelikleriyle değil, aynı zamanda bireysel tüketicilerin değerlendirmesiyle de ilgili olduğunu vurgulamaktadır. Tüm tüketiciler arasında özgünlük kavramı hakkında tek bir tanım olmadığından, marka özgünlüğü çeşitli niteliklere ve boyutlara karşılık gelir (Oh vd., 2019, s. 4). Genel olarak özgünlük kavramının tanımları farklıdır. Bununla birlikte, markanın özgünlüğünün belirli bir bağlamı için aşağıdaki sonuçlar çıkarılabilir (Bruhn vd, 2012, s. 567):

(1) Markaların bağlamındaki orijinallik, insanlığın orijinalliğinin aksine, pazar tekliflerinin gerçekliği (nesneler ve hizmetler) ile ilgilidir;

(2) Marka özgünlügü̈, yalnızca markanın kendine özgü nitelikleri ile ilgili olmak yerine bireylerin değerlendirmelerine dayanmaktadır;

(3) Marka özgünlüğü, özellikle marka bağlamında özgünlük kavramının benzersiz bir tanımı olmadığı için çeşitli özelliklere karşılık gelir.

Özet olarak, marka özgünlüğü, bir markanın temel değerlerini yansıtan davranışının algılanan tutarlılığı ve kendisi için doğru olarak algılanan, marka özünü veya esaslı doğasını zedelemeyen normlardır (Fritz vd., 2017, s. 327). Marka özgünlüğü, anlam ve gerçek benlik arayan tüketiciler için bir değer önerisidir (Arnould ve Price, 2000; Beverland ve Farrelly, 2010). Tüketiciler, tükettikleri ürünler ve markalar aracılığıyla yaşamlarında özgünlük arzusundadırlar (Bruhn vd., 2012). Özgünlüğe verilen özlemsel değeri yansitan önceki araştırmalar, marka özgünlügünün tüketicilerin markalara verdiği tepkileri olumlu yönde etkilediğini göstermiştir (Napoli vd., 2014; Morhart vd, 2015). Özgün bir imajı olduğu düşünülen markalarla hem sembolik hem de duygusal bağlanma daha yüksektir (Ballantyne vd., 2006). Özgün olarak algılanan bir marka daha olumlu değerlendirilirse, bu tür bir marka özgünlüğü algısı, gelecekte bir mağazayı / web sitesini ziyaret etmek, bir ürün satın almak ve markayı diğer insanlara tavsiye etmek açısından tüketicilerin markaya yönelik davranışsal niyetlerini olumlu yönde etkilemelidir (Oh vd., 2019, s. 4). Beverland vd., (2008) özgünlük; algılar, inançlar ve deneyimlerin yaratıcıları olarak müşteriler tarafından oluşturulur (Busser ve Shulga, 2019, s. 5). Benzersiz ve kültürel deneyimler için tüketici araylşında benzeri görülmemiş bir büyüme ile, özgünlük önemli bir satın alma kriteri ve bir markalama aracı (Chhabra, 2010). Sonuç olarak marka özgünlüğü, duygusal bağlantılar kurarak ve tüketici davranışını olumlu yönde etkileyerek pazarın büyümesini hızlandırabileceğinden çağdaş pazarlamanın temel taşı haline gelmiştir (Chhabra ve Kim, 2018, s. 55). 


\section{Marka İmaj1}

İmaj, tüketicilerin işletmeler hakkındaki algılarıdır ve algılamalar işletmenin kimliği, ürünleri, ideolojisi gibi özellikleri ile ilişkilendirilir (Çavuşoğlu ve Durmaz, 2020, s. 76). Keller (1993)'e göre, marka imajı tüketicilerin hafizadaki marka ilişkilerinden oluşan bir marka hakkındaki algılarını kapsamakta ve "tüketici belleğinde tutulan marka birlikleri tarafından yansitılan bir markaya ilişkin algılamalar" olarak tanımlanmaktadır (Michaelidou vd., 2015, s. 1657).

Kotler ve Armstrong (1996), marka imajinı "belirli bir marka hakkında bir dizi inanç" olarak tanımlamaktadır (Chang ve Liu, 2009, 1689). Keller (1993)'e göre, marka imajı, özellikler (ürünle ilgili ve ürünle ilgili olmayan), faydalar (işlevsel, sembolik, deneyimsel) ve tutumlar dahil olmak üzere marka iştiraklerinin birleşimidir (Cho vd., 2014, s. 30). Bazı tüketiciler fonksiyonel faydayı ön plana çıkartırken bazı tüketiciler de sembolik faydayı ön plana çıarmaktadır (Demirağ ve Durmaz, 2020, s. 58). Marka imajı, marka hakkında tüketicinin zihninde yer alan öznel ve algısal olgular bütünün toplamıdır. Dolayısıyla, markayla ilgili sembolik ve fonksiyonel algılar marka imajını oluşturmaktadır. Diğer bir ifadeyle, tüketiciler, marka hakkında sahip oldukları bilgileri ve markayla ilgili hatırladıkları bütün çağrışımları kullanarak zihinlerinde o markanın imajını oluştururlar (Keller, 1993, s. 3). Uztuğ (2003)'a göre marka imajı, tüketicilerin zihninde, anlamlı bir şekilde örgütlenmiş bir ilişki şeklinde çeşitli iletişim sonucunda ortaya çıkan algıdır (Dülek ve Saydan, 2019, s. 472).

Marka imajı, markanın çağrıştırdıklarına ve özelliklerine yönelik bir bütündür (Diker ve Özüpek, 2013, s. 103). Tüketicilerin belli bir markayı nasıl algıladığını ifade eden kavram marka imajıdır (Sarıçiçek vd., 2017, s. 349). Marka İmajı; tüketicinin markayı nasıl algıladığı (Aaker, 1996, s. 69), marka ve hizmetlerden yankılanan sinyallerin algı şekli (Arnold, 1992, s. 94), tüketicilerde markanın öznel bir zihinsel resmi (Riezebos, 2003, s. 63) olarak tanımlanmış ve bu tanımların ortak noktası ise imajin tüketici belleğinde oluşan bir süreç olarak değerlendirilmiştir (Demirağ ve Çavuşoğlu, 2019, s. 16).

Marka imajl; tüketicilerin, belli markalara gösterdikleri mantıklı ve duygusal algılamaları (Dobni ve Zinkhan, 1990), sembolik marka inançlarını (Dolich, 1969), hafızada tutulan marka yansımalarını (Saleem ve Raja, 2014), ürün hakkındaki genel izlenimleri (Mohajerani ve Miremadi,2012), ürün 
özelliklerin tüketicilere hatırlattıkları tutumları (Aksoy, 2018, s. 1459), belirli bir marka ile ilişkilendirdikleri algıları (Cho ve Fiore, 2015, s. 255) ve nihayetinde tüketicilerin aklına gelen ilk şey olarak (Durmaz vd., 2018, s. 531) ifade edilmiştir.

\section{Marka Tercihi}

Pazarlamada tercih kavramı, alternatifler arasinda arzu edilebilirlik veya seçim anlamına gelir (Oliver ve Swan, 1989). Marka tercihi uzun zamandır tüketicilerin marka niteliklerinin rasyonel temelde bilişsel yargısına odaklanan geleneksel modeller kullanılarak açıklanmıştır. Bununla birlikte, deneyimsel pazarlamaya geçiş, markalaşmanın temel taşı, markanın rolünü bir dizi özellikten deneyimlere genişletti. Ayrıca marka tercihi tüketici davranışının rasyonel ve irrasyonel yönlerini de göz önünde bulundurur (Ebrahim vd., 2016, s. 1230). Zajonc ve Markus (1982, s. 128) “bir tercihin, bireyin nesne hakkında ne düşündüğü veya ne söylediği konusunda değil, ona nasıl davrandığı konusunda kendisini çok fazla gösteren davranışsal bir eğilimdir" şeklinde ifade etmişlerdir.

Marka tercihi, müşterinin mevcut şirketi tarafından sağlanan belirlenmiş hizmeti, değerlendirme kümesinde diğer şirketler tarafından sağlanan belirlenmiş hizmetle karşılaştırıldığında ne ölçüde desteklediği şeklinde tanımlamaktadır ( Hellier vd, 2003, s. 1765). Yinemarka tercihi, markayı seçme ve kullanma konusunda göreli tercih olarak tanımlanmaktadır (Chomvilailuk ve Butcher, 2010, s. 400).Marka tercihi, bir markanın diğer benzer markalara göre tercih edildiğine dair tüketici inancı olarak görülebilir (Wang, 2015, s. 555-556).

\section{Marka Güveni}

Pazarlamanın nihai hedefi, tüketici ile marka arasında yoğun bir bağ oluşturmaktır ve bu bağın ana bileşeni güvendir. Bunun nedeni, güvenin bir markanın sahip olabileceği en önemli özellik iken, ilişkinin temel taşı ve bir ilişkide en çok istenen niteliklerden biri olarak görülmesidir (Yannopoulou vd., 2011, s. 531-532).

Marka güveni, markanın belirttiği işlevi yerine getirmeye olan inançın tüketicide karşılık bulması (Uzunkaya, 2017, s. 34), ortalama bir tüketicinin markanın belirtilen işlevini yerine getirme yeteneğine güvenme isteği (Cha- 
uduri ve Holbrook, 2001, s.82), tüketicinin bir hizmeti seçerken algilanan riski azaltan (Han vd., 2015, s.85), markanın algılanan güvenilirliği (Folse vd., 2013, s. 333), bir tüketicinin markanın güvenilirliğine ve bütünlüğüne duyduğu güven (Chatterjee ve Chaudhuri, 2005, s. 2),markanın tüketiciyle çıkarları ve refahından güvenilir ve sorumlu olduğu algısına dayanacak şekilde (Lee vd., 2014, s. 11), tüketicinin marka ile etkileşimi sırasında sahip olduğu bir güvenlik hissi olarak tanımlanmıştır (Ha ve Perks, 2005, s. 443; Lassoued ve Hobbs, 2015, s. 1). Marka güveni, ortalama tüketicinin markanın belirtilen işlevini yerine getirme yeteneğine güvenme isteğidir (Ha ve Perks, 2005, s. 443).

\section{Kuramsal Çerçeve}

Napoli vd., (2014) marka özgünlüğü ve marka güveni, marka güvenilirliği ve tüketicilerin satın alma niyeti arasında pozitif bir ilişki olduğunu göstermektedir. Özgünlük ayrıca bir markanın mirasının korunmasını sağlar ve bir markaya karşı daha yüksek düzeyde tüketici memnuniyeti ve bir marka ile bağlantı kurulmasını kolaylaştırır (Leigh vd., 2006). Tüketicilerin bir markanın özgünlüğüne ilişkin algıları, kalite algıları, ödeme istekliliği, marka imajı ve marka tatmini gibi marka ile ilgili diğer bilişler üzerinde de olumlu bir etkiye sahip olabilir (Napoli vd., 2016, s. 1206). Marka güveni, tüketicinin bir markanın beklendiği veya vaat edildiği gibi performans göstereceğine ve bir firmanın ortaya çıkabilecek sorunları veya sorunları çözmeye çalışacağ 1 inancına ilişkindir (Delgado-Ballester, 2004).

Marka özgünlüğünün marka güveni üzerinde olumlu bir etkisi olduğu düşünülmektedir (Portal vd., 2018, s. 1). Oldukça özgün bir markanın benzersiz, güvenilir ve kaliteli bir güvence içerdiği düşünülür ve tüketiciler bu markanın "vaadine" (Fritz ve Schoenmueller, 2017) yeterince güvenir, böylece yaşam memnuniyetini arttırır ve olumlu duyguları tetikler (Jian vd., 2019, s. 5). Yine Busser ve Shulga (2019) çalışmalarında, özgünlüğün güven üzerinde güçlü ve olumlu bir etkisi olduğunu belirtmişlerdir (Busser ve Shulga, 2019, s. 1768).

Marka özgünlüğü, “bir markaya atfedilen özgünlüğün öznel bir değerlendirmesidir" (Napoli vd. 2014, s. 1091). Önceki araştırmalar, tüketicilerin bir markayı vaatlerine sadık kaldıklarına, güvenilir iddialarda bulunduklarına ve dürüst ve şeffaf olduklarına inandıklarında özgün olarak gördükle- 
rini göstermektedir. Güvenilir ve güvenilir olduğu düşünülen markalar genellikle özgün olarak algılanır (Luffarelli vd., 2019, s. 3).

Fritz Heider, kişisel özgünlük kavramına bir atıf teorisi uygulayan ilk kişilerden biriydi (Heider, 1958). Heider, bir kişinin aktif bir eylem algılayıcısı olarak, belirli sonuçların neden ortaya çıktı̆̆ı konusunda sürekli olarak nedensel çıarımlarda bulunduğunu savunur. İnsanlar çevrelerinde yön bulmak için bu şekilde hareket ederler. Teori insanların rasyonel bir şekilde nedensel atıflar yaptığını ve bir eylemin nedenini söz konusu eylemle en çok değişen faktöre tayin ettiklerini varsayar (Schallehn vd., 2014, s. 193).

Coary (2013) çalışmasında, özgünlük boyutlarını atıfla ilişkilendirmiş ve bu boyutların, tüketici ürünlerine özgünlüğü atfetmek için kullanıldığını ifade etmiştir (Coary, 2013, s. 9). Tüketiciler bir markaya atfedilen anlamlara aracılık ederek marka özgünlügünü değerlendirmede farklılık gösterebilirler (Pattuglia ve Mingione, 2017, s. 38). Özetle atıf teorisi (Ketron, 2016, s. 34), bireylerin bir olayın, eylemin, davranışın neden oluştuğunu anlamaya çalıştığını ve o olayın, eylemin, davranışın arkasındaki güdünün içsel (içsel olarak motive edilmiş) veya dışsal (durumsal) olup olmadığını anlamaya çalışmaktadır (Yakut, 2018, s. 356). Atfetme Teorisi (Nedensellik Yükleme Teorisi) insanların rasyonel bir şekilde nedensel atıflar yaptığını ve bir eylemin nedenini söz konusu eylemle en çok değişen faktöre tayin ettiklerini varsayar (Schallehn vd., 2014, s. 193). Dolayısıyla tüketici tarafından ürünün marka özgünlüğüne sahip olduğunun düşünülmesi ve böyle bir atıf yapılması o markanın tercih edilmesinde oldukça etkili olacaktır.

Liao ve Ma (2009)'ya göre, tüketiciler bir nesnenin özgünlüğünü değerlendirmek ve özgünlüğün farklı faydalarından yararlanmak için farklı ipuçlarına güvenmektedir (Napoli vd., 2016, s. 1207). "Güvenilir markalar, sürdürülebilir pazar başarısı ve topluluk itibarı inşa etmeyi arzulayan şirketler için, özgün olma zorunluluğu kaçınılmaz olarak önem kazanacaktır" (Arthur W. Page Society, 2007, s. 7). Güven, süreç ve davranış üzerinde 1lımlı bir etkiye sahiptir (Liao ve Chen, 2016, s. 2).

Fritz ve Schoenmueller (2017), gerçekte, tüketiciler daha yüksek özgünlüğe sahip markaları tercih edecektir. Marka özgünlüğü açısından, bir marka tüketicinin gerçek uyumunu yansitır ve gerçekleştirir (Jian vd., 2019, s. 5). Yapılan çalışmalar özgünlüğün; değer, kişilik, kimlik, imaj, konumlandırma, prestij, farkındalık ve taahhüt gibi marka ile ilgili pek çok kavramı kapsadığını, dolayısıyla marka konusunda bir şemsiye vazifesi gördüğünü 
ortaya koymaktadır (Schallehn vd., 2014, s. 194; Spiggle, S., Nguyen, H. T. ve Caravella, M., 2012, s. 968).

Konukseverlik araştırmasında Lu vd., (2015) , etnik bir restoranın özgünlüğü ve marka farkındalığının, marka imajının ve algılanan kalitenin marka değeri boyutlarıyla ilgili algılamalar arasında pozitif bir ilişki olduğunu göstermektedir (Fritz vd., 2017, s. 330).

Hem Kwon (1990) hem de Keller (2003), olumlu marka imajinın marka tercihine yol açtığını makul bir şekilde belirtmektedir (Alamro, 2010, s. 69). Sharp (2003), marka imajinın tüketici karar alma sürecini ve marka seçimini doğrudan etkilediğini belirlemiştir (Maore vd., 2019, s. 162-163). Marka imaj1, tüketicilerin satın alma karar verme sürecinde önemli bir ipucudur. Tüketicilerin olumlu marka imajı ile iyi bilinen marka ürünleri satın alma olasılığ1 daha yüksektir, çünkü daha olumlu imajı olan bir marka tüketicilerin alg1lanan risklerini azaltma etkisine sahiptir (Wang ve Tsai, 2014, s. 29).

Kotler ve Armstrong (1996), marka imajın "belirli bir marka hakkında bir dizi inanç" olarak tanımlamaktadır. Bu inançlar kümesi, müşteriler alternatif markaları değerlendirdiklerinde alıcının karar verme sürecinde önemli bir rol oynamaktadır (Chang ve Liu, 2009, s. 1689).

Ling vd., (2011) çalışması da güven ve satın alma niyetleri arasındaki pozitif ilişkiyi desteklemiştir. Johnson'un (2007) bankacılık alanında yaptığ çalışmada, firmaya duyulan güvenin, firmadan algılanan değer üzerinde önemli ve olumlu bir etkisi olduğunu belirtmişlerdir. Chong, Yang ve Wong (2003), güven ve satın alma niyetleri arasındaki değerin aracı rolü olduğunu ortaya koymuşlardır (Lien vd., 2015, s. 3).

Harris ve Goode (2010)'e göre güven, tüketicilerin satın alma niyetini etkileyebilir (Chen vd., 2018, s. 7). Bir markaya güvenen tüketiciler, o markaya sadık kalmaya, yeni kategorilerde veya mevcut markalarda tanitılan yeni markaları satın almaya, markaya daha üstün bir fiyat ödemeye ve tüketicilerin zevkleri hakkında aynı bilgileri paylaşmaya daha istekli davranış ve tercihler ortaya koyarlar (Mabkhot vd., 2017, s. 73).

Lee ve Tan (2003)' a göre marka imajinın genellikle müşterilerin veya tüketicilerin hafızasında tutulan bir marka ve marka çağrışımları hakkındaki algılarla yansıtıldığını ortaya koymaktadır. Bu nedenle, marka imajı, doğası gereği ürün özellik bilgileri için önemli bir destek görevi görebilir ve bu da müşterilerin bir markaya olan güvenini artırır (Pavlou vd., 2007). Cretu ve Brodie (2007)'a göre, müş̧terilerin bir markaya olan güveni ne kadar fazla 
olursa, o markaya güvenme olasılıkları o kadar artar. Önceki araştırma bulguları, marka imajı ve marka güveni arasında pozitif bir bağlantıyı desteklemektedir (Chinomona, 2016, s. 131).

Chaudhuri ve Holbrook (2001, s. 82) marka güvenini “ortalama bir tüketicinin markanın belirtilen işlevini yerine getirme yeteneğine güvenme isteği" olarak tanımlamaktadır. Marka güveni genellikle marka bağlılı̆̆ının ana belirleyicisi olarak görülür çünkü tüketiciler ve tercih ettikleri markalar arasında uzun vadeli ilişkiler kurmada kritik bir rol oynar. Birçok çalışma ampirik olarak memnuniyet ve güven arasında ve güven ile müşteri sadakati arasında güçlü ve pozitif bir ilişki olduğunu göstermiştir. Liang ve Wang (2007) müşteri memnuniyetinin güvenin iyi bir yordayıcısı olduğunu belirtmektedir ve güvenin müşteri sadakati üzerinde güçlü bir pozitif etkiye sahip olduğunu öne sürmüşlerdir (Menidjel vd., 2017, s. 4). Marka başar1sında güven dikkate alınması gereken kilit bir faktördür (Rajavi vd., 2019, s. 4). Güven oluşturma süreci, bir markanın vaatlerini yerine getirme yeteneğinden kaynaklanmaktadır. Tüketiciler, müşterilerine verdiği sözleri (örneğin, vaat edilen ürün kalitesi, vaat edilen hizmetler) yerine getirebilecek daha prestijli bir marka görebilmeyi isterler (He vd., 2016, s. 7). Bu nedenle güvenin bir çok değişkenle ilişkilendirilerek aracılık edeceği değerlendirilmektedir.

Yapılan çalışmalar özgünlüğün; değer, kişilik, kimlik, imaj, konumlandırma, prestij, farkındalık ve taahhüt gibi marka ile ilgili pek çok kavramı kapsadığını, dolayısıyla marka konusunda bir şemsiye vazifesi gördüğünü ortaya koymaktadır (Schallehn vd., 2014, s. 194; Spiggle, S., Nguyen, H. T. ve Caravella, M., 2012, s. 968). Yapılan yazın taramasında, marka özgünlügünü marka tercihi, marka sadakati, marka bağl1lığı ve marka güveni ile ilişkilendirildiği görülmüştür (Demirel ve Yıldız, 2015; Eggers vd., 2013; Assiouras, 2015). Bu bulgular ışığında aşağıdaki hipotezler geliştirilmiştir.

- H1. Marka özgünlüğü, marka imajını pozitif etkilemektedir.

- Hia Marka özgünlügünün alt boyutu olan erdem, marka imajını pozitif etkilemektedir.

- Hıb Marka özgünlüğünün alt boyutu olan bağlantı, marka imajını pozitif etkilemektedir.

- Hic Marka özgünlüğünün alt boyutu olan gerçeklik, marka imajını pozitif etkilemektedir. 
- H1d Marka özgünlüğünün alt boyutu olan estetik, marka imajını pozitif etkilemektedir.

- He Marka özgünlüğünün alt boyutu olan kontrol, marka imajını pozitif etkilemektedir.

- Hif Marka özgünlüğünün alt boyutu olan orjinallik, marka imajın pozitif etkilemektedir.

- H2. Marka özgünlügüu, marka tercihini pozitif etkilemektedir.

- $\mathrm{H}_{2 \mathrm{a}}$ Marka özgünlüğünün alt boyutu olan erdem, marka tercihini pozitif etkilemektedir.

- $\quad \mathrm{H}_{2 b}$ Marka özgünlüğünün alt boyutu olan bağlantı, marka tercihini pozitif etkilemektedir.

- $\mathrm{H}_{2 c}$ Marka özgünlügünün alt boyutu olan gerçeklik, marka tercihini pozitif etkilemektedir.

- $\mathrm{H}_{2 \mathrm{~d}}$ Marka özgünlüğünün alt boyutu olan estetik, marka tercihini pozitif etkilemektedir.

- $\quad H_{2 e}$ Marka özgünlügünün alt boyutu olan kontrol, marka tercihini pozitif etkilemektedir.

- $\mathrm{H}_{2 f}$ Marka özgünlügünün alt boyutu olan orjinallik, marka tercihini pozitif etkilemektedir.

- H3. Marka imajı marka tercihini pozitif etkilemektedir.

- H4. Marka güveninin, marka özgünlüğü ile marka imajı ilişkisinde aracı rolü bulunmaktadır.

- H5. Marka güveninin, marka özgünlügü ile marka tercihi ilişkisinde aracı rolü bulunmaktadır.

\section{Yöntem}

\section{Araştırma Modeli}

Araştırmada geliştirilen modelde, marka özgünlüğü ve alt boyutlarının marka imajı ve tercihini etkileyeceği ve marka güveninin marka özgünlüğü, marka imajı ve tercihinde aracı etkiye sahip olacağı düşünülmektedir. 


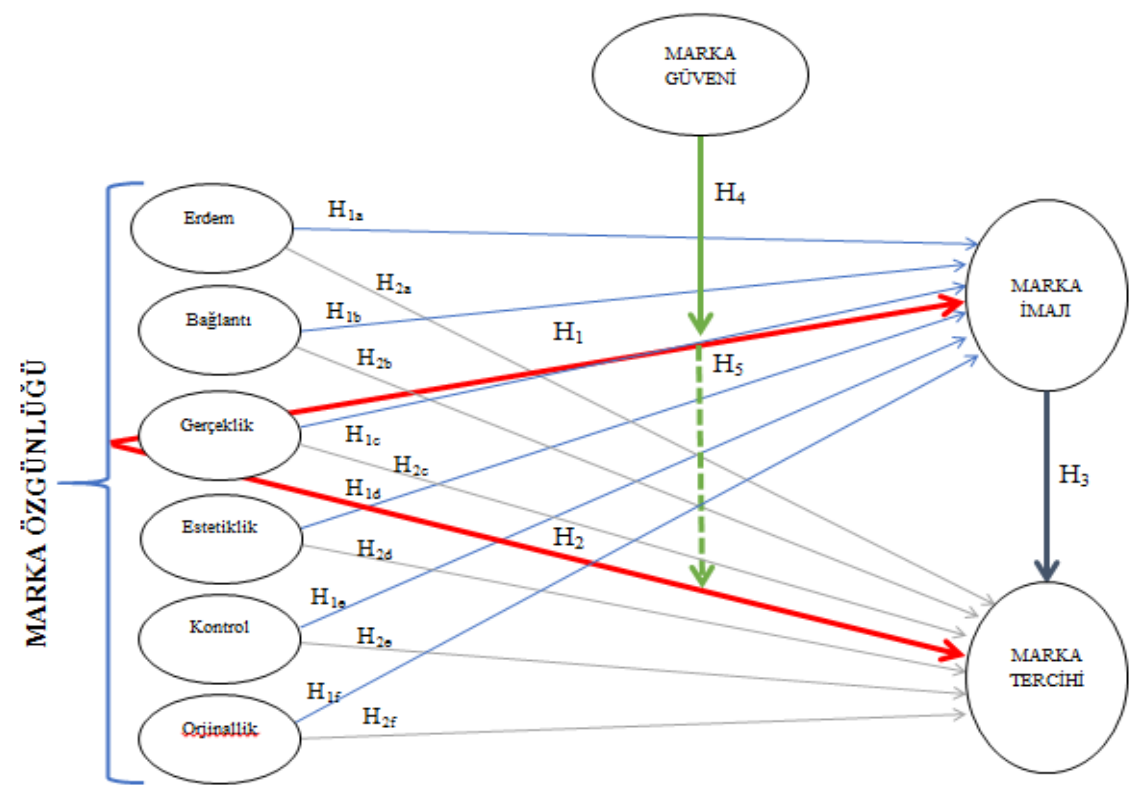

Şekil 1. Araştırma Modeli

\section{Evren ve Örneklem}

Araştırmanın evrenini Gaziantep ilinde ikamet eden beyaz eşya satın alan müşteriler oluşturmaktadır. Araştırma kapsamında, olasılıklı olmayan örneklem yöntemlerinden kolayda örneklem metodu kullanılmıştır. Bu araştırmada 1083 anket dağıtılmıştır. 2019 yılında toplanan anketlerden 816 anket analiz için kullanılmıştır.

Pilot Uygulama: Yapılan pilot uygulamada; marka özgünlüğü, marka imajı, marka tercihi ve marka güveni ölçeklerinin toplam varyansı açılama oranlarının ve Kaiser-Meyer-Olkin (KMO) testlerinin örneklem yeterlilik değerinin faktör analizi için yeterli olduğu belirlenmiştir.

\section{Veri Toplama Araçlan ve Geçerlilik Güvenirlik Analizleri}

Araştırmada veri toplama tekniği olarak anket formu kullanılmıştır. Çalışmanın anketi, oluşturulan amaçlar doğrultusunda ilgili alan yazın dikkate alınarak hazırlanmıştır. Araştırma çerçevesinde, geniş bir alan yazın taraması yapılarak ölçekler araştırılmıştır. Yabancı literatürdeki ölçeklerin ta- 
mamı Türkçe'ye çevrilmiştir.ìlk bölümde marka özgünlüğü 18 maddede, marka imaj1 8 maddede, marka tercihi 4 maddede ve marka güveni 5 maddede ölçülmüştür. Bu kapsamda son bölümde hipotezlerin testi için toplam 35 maddeye yer verilmiştir. Bu bölümün ölçekleri için oluşturan ifadelerin tümü 5'li likert tipi (Kesinlikle Katılmıyorum=1, Kesinlikle Katılıyorum=5) şeklinde derecelendirilmiştir. İkinci bölümde ise araştırmaya katılanlar hakkında tanımlayıc bilgiler elde edilmesi amacıyla demografik bilgileri tespit etmeye yönelik sorular bulunmaktadır.

Tablo 1. Araştırmada Kullanılan Ölçekler

\begin{tabular}{lll}
\hline Ölçülen Boyutlar & Kaynak & Madde Sayısı \\
\hline Marka Özgünlüğü & Van-Dat Tran ve Ching-Jui Keng(2018) & 18 \\
\hline Marka İmaji & Salinas ve Perez (2009) & 8 \\
\hline Marka Tercihi & Chang ve Liu (2009) & 4 \\
\hline Marka Güveni & $\begin{array}{l}\text { Nicole Koschate-Fischer ve Susanne } \\
\text { Gartner (2015) }\end{array}$ & 5 \\
\hline
\end{tabular}

Marka Özgünlü̆̆̈̈ Ölçeği: Bu araştırmada Tran ve Keng (2018) tarafından geliştirilen marka özgünlügü ölçeği kullanılmıştır. Yapılan KFA sonucunda, marka özgünlüğünün 6 faktörlü yapısı elde edilmiştir. Marka özgünlüğüne ait faktörlerin yükleri 0,658 ile 0,855 aralığındadır. Erdem boyutuna ait ifadelerin faktör yükleri 0,667 ile 0,855 , bağlantı alt boyutuna ait ifadelerin faktör yükleri 0,753 ile 0,808 , gerçeklik alt boyutuna ait ifadelerin faktör yükleri 0,669 ile 0,740, estetiklik alt boyutuna ait ifadelerin faktör yükleri ise 0,733 ile 0,769 kontrol alt boyutuna ait ifadelerin yükleri 0,658 ile 0,724 ve orjinallik alt boyutunun faktör yükleri ise 0,719 ile 0,785 aralığındadır. Her bir faktöre ait ifadelerin faktör yüklerinin 0,50'nin üzerinde olduğu tespit edilmiştir.

Ayrıca KMO testiyle örneklem yeterlilik değerinin 0,938 olduğu ve örneklemin faktör analizi için yeterli olduğu tespit edilmiştir. Ayrıca, Bartlett küresellik testinin anlamlı olması, [ $\chi 2$ (136)=9836,773, @<0.005] maddeler arasındaki korelasyonların faktör analizi için uygunluğunu göstermektedir.

Marka İmajı Ölçeği: Marka İmajı Salinas ve Perez (2009) tarafından yapılan çalışmadan uyarlanan ölçek kullanılmıştır. Ölçek tek boyuttan ve 8 maddeden oluşmaktadır. Orijinal ölçeğin İngilizce olması sebebiyle Türkçe'ye çevirme işlemleri gerçekleştirilmiştir. Yapılan KFA sonucunda, algılanan değer alanyazına uygun olarak tek faktörlü bir yapıya ulaşılmıştır. Ölçeğin 
faktör yükleri 0,847 ile 0,910 aralığında olduğu görülmüştür. Yapılan KFA sonucunda her bir faktöre ait faktör yüklerinin 0,50'nin üzerinde olduğu tespit edilmiştir. Ayrıca KMO testiyle örneklem yeterlilik değerinin 0,916 olduğu ve örneklemin faktör analizi için yeterli olduğu tespit edilmiştir. Ayrıca, Bartlett küresellik testinin anlamlı olması, $[\chi 2(21)=5208,809$, $\varrho<0.005]$ maddeler arasındaki korelasyonların faktör analizi için uygunluğunu göstermektedir. Marka imajının güvenilirlik düzeyinin 0,94 olduğu tespit edilmiştir.

Marka Tercihi Ölçeği: Bu konuda Chang ve Liu (2009)'nun hizmet sektörüne yönelik gerçekleştirdikleri çalışmada kullanmış oldukları marka tercihi ölçeği kullanılmıştır. Ölçek; tek boyuttan ve 4 maddeden oluşmaktadır. Orijinal ölçeğin İngilizce olması sebebiyle Türkçeye çevirme işlemleri gerçekleştirilmiştir. Yapılan KFA sonucunda, literatüre uygun olarak tek faktörlü bir yapıya ulaşılmıştır. Ölçeğin faktör yükleri 0,833 ile 0,898 aralığında olduğu görülmüştür. Ayrıca KMO testiyle örneklem yeterlilik değerinin 0,837 olduğu ve örneklemin faktör analizi için yeterli olduğu tespit edilmiştir. Ayrıca, Bartlett küresellik testinin anlamlı olması, [ $\chi 2$ (6) $=2051,273$, $\varrho<0.005]$ maddeler arasındaki korelasyonların faktör analizi için uygunluğunu göstermektedir. Marka tercihinin güvenilirlik düzeyinin 0,90 olduğu tespit edilmiştir.

Marka Güveni Ölçeği: Bu konuda Nicole Koschate-Fischer ve Susanne Gartner (2015)'in geliştirdikleri marka güveni ölçeği kullanılmıştır. Orijinal ölçeğin İngilizce olması sebebiyle Türkçeye çevirme işlemleri gerçekleştirilmiştir. Yapılan KFA sonucunda, alanyazına uygun olarak tek faktörlü bir yapıya ulaşılmıştır. Ölçeğin faktör yükleri 0,795 ile 0,867 aralığında olduğu görülmüş̧ür. Ayrıca KMO testiyle örneklem yeterlilik değerinin 0,853 olduğu ve örneklemin faktör analizi için yeterli olduğu tespit edilmiştir. Ayrıca, Bartlett küresellik testinin anlamlı olması, [ $\chi 2(10)=2589,347, \varrho<0.005]$ maddeler arasındaki korelasyonların faktör analizi için uygunluğunu göstermektedir. Marka güveninin güvenilirlik düzeyinin 0,90 olduğu tespit edilmiştir.

Tablo 2. Uyum İyiliği Değerleri

\begin{tabular}{|c|c|c|c|c|c|c|c|}
\hline & $\begin{array}{ll}\chi^{2} & \mathrm{sd} \\
\end{array}$ & & \multicolumn{2}{|c|}{$\chi^{2} /$ sd GFI } & \multicolumn{2}{|c|}{ CFITLI } & \multirow{2}{*}{$\begin{array}{l}\text { RMSEA } \\
\leq, 08\end{array}$} \\
\hline Kriter & & & $\leq 5$ & $\geq, 85$ & $\geq, 90$ & $\geq, 90$ & \\
\hline Yapısal Model & 1027,109 & 319 & 3,220 & ,914 & ,963 & 956 & 052 \\
\hline
\end{tabular}


Araştırma modeli uyum iyiliği değerleri incelenmiş ve modelin iyi bir uyum iyiliğine sahip olduğu tespit edilmiştir. Değişkenlerin KFA ve DFA sonucunda ölçeğin geçerliliği için yeterli kanıt toplanmıştır.

\section{Araştırma Modelinin Test Edilmesi ve Bulgular}

Tablo 3. Korelasyon Analizi Sonuçlan

\begin{tabular}{|c|c|c|c|c|c|c|c|c|c|}
\hline & 1 & 2 & 3 & 4 & 5 & 6 & 7 & 8 & 9 \\
\hline 1.Erdemlilik & $\begin{array}{l}(.82) \\
\end{array}$ & & & & & & & & \\
\hline 2.Bağlantı & $479^{* *}$ & (.78) & & & & & & & \\
\hline 3.Gerçeklik &, $502^{* *}$ &, $595 \%$ & & & & & & & \\
\hline 4.Estetiklik & $435^{* *}$ &, $578^{* *}$ &, $766^{* *}$ & $(.87)$ & & & & & \\
\hline 5.Kontrol &, $421^{* *}$ &, $515^{* *}$ &, $741^{* *}$ &, $739^{* *}$ & (.88) & & & & \\
\hline 6.Orjinallik & $385^{* *}$ &, $515^{* *}$ & ,657** & ,658** & $681^{* *}$ & $(.87)$ & & & \\
\hline 7.Marka İmajı & $419^{* *}$ &, $543 *$ & , $718^{* *}$ & $720^{* *}$ &, $775^{* *}$ &, $744^{* *}$ & $(.94)$ & & \\
\hline 8.Marka Tercihi & $382^{* *}$ & $434^{* *}$ &, $614^{* *}$ & $653^{* *}$ &, $653^{* *}$ &, $587^{* *}$ &, $773^{* *}$ & $(.90)$ & \\
\hline 9.Marka Güveni & $295^{* *}$ &, $507^{* *}$ &, $626^{* *}$ & $642^{* *}$ & ,666 & $651^{* *}$ &, $763^{* *}$ & ,711** & $(.90)$ \\
\hline
\end{tabular}

Araştırma modelinde yer alan ölçeklere yönelik yapılan korelasyon analizi sonucunda marka özgünlüğü alt boyutlarının marka imajı, marka tercihi ve marka güveni boyutları ile arasında olumlu yönde anlamlı bir ilişkiye sahip olduğu tespit edilmiştir.

\section{Tablo 4.Yapısal Eşitlik Modeli Regresyon A ğırlıklan}

\begin{tabular}{lllllll}
\hline Değişkenler & \multicolumn{1}{l}{ Test Edilen Yol } & Tahmin & Std. Hat. & Kritik Oran & P \\
\hline Erdem & $\longrightarrow$ & Marka İmaji &, 007 &, 046 &, 251 &, 802 \\
\hline Bağlantı & $\longrightarrow$ & Marka İmaji &, 139 &, 056 & 3,212 &, 001 \\
\hline Gerçeklik & $\longrightarrow$ & Marka İmaji &,- 015 &, 071 &,- 238 &, 812 \\
\hline Estetiklik & $\longrightarrow$ & Marka İmaji &, 087 &, 068 & 1,440 &, 150 \\
\hline Kontrol & $\longrightarrow$ & Marka İmaji &, 436 &, 061 & 7,772 &, 000 \\
\hline Orijinallik & $\longrightarrow$ & Marka İmaji &, 328 &, 044 & 7,717 &, 000 \\
\hline Erdem & $\longrightarrow$ & Marka Tercihi &, 086 &, 057 & 2,436 &, 015 \\
\hline Bağlantı & $\longrightarrow$ & Marka Tercihi &,- 093 &, 069 & $-1,794$ &, 073 \\
\hline Gerçeklik & $\longrightarrow$ & Marka Tercihi &,- 065 &, 086 &,- 859 &, 390 \\
\hline Estetiklik & $\longrightarrow$ & Marka Tercihi &, 259 &, 084 & 3,623 &, 000 \\
\hline Kontrol & $\longrightarrow$ & Marka Tercihi &,- 016 &, 081 &,- 217 &, 828 \\
\hline Orijinallik & $\longrightarrow$ & Marka Tercihi &,- 099 &, 057 & $-1,846$ &, 065 \\
\hline Marka İmaj1 & $\longrightarrow$ &, 070 & 11,918 &, 000 \\
\hline
\end{tabular}

Elde edilen sonuçlar incelendiğinde; $\mathrm{H}_{1 \mathrm{~b}}, \mathrm{H}_{1 e}, \mathrm{H}_{11}, \mathrm{H}_{2 \mathrm{a}}$ ve $\mathrm{H}_{2 \mathrm{~d}}$ hipotezleri kabul edilirken $\mathrm{H}_{1 \mathrm{a}}, \mathrm{H}_{1}, \mathrm{H}_{1 \mathrm{~d}}, \mathrm{H}_{2 b}, \mathrm{H}_{2 c}, \mathrm{H}_{2 \mathrm{e}}$ ve $\mathrm{H}_{2 \mathrm{f}}$ hipotezleri kabul edilmiştir.

Araştırmanın amacı doğrultusunda $\mathrm{H} 1$ ve $\mathrm{H} 2$ 'nin testi için ayrıca model oluşturulmuştur. Oluşturulan modelin yol analizi sonuçları Tablo 5'de gösterilmiştir. 
Tablo 5.Yapısal Eşitlik Modeli Regresyon Ağırlıkları

\begin{tabular}{lrrrrr}
\hline Test Edilen Yol & Tahmin & Std. Hata & Kritik Oran & P & \\
\hline Marka Özgünlüğ̈̈ $\longrightarrow$ Marka İmaji &, 887 &, 401 & 7,452 &, 000 \\
\hline Marka Özgünlü̆ğ̈ $\longrightarrow$ Marka Tercihi &, 803 &, 369 & 7,332 &, 000 \\
\hline
\end{tabular}

Elde edilen sonuçlar incelendiğinde $\mathrm{H} 1$ ve $\mathrm{H} 2$ hipotezlerinin kabul edildiği görülmüştür.

\section{Marka Güveni Aracılık Rolü}

Aracı değişken, bağımlı ve bağımsız değişken arasında bağlantı kurmaktadır. Dolayısıyla bağımlı değişken ile bağımsız değişken arasında anlamlı bir ilişki olması beklenmektedir (Gürbüz ve Şahin, 2016: 286). Araştırma modeline göre $\mathrm{H}_{4}$ ve $\mathrm{H}_{5}$ hipotezleri aracıllk etkisinin belirlenmesi amaciyla incelenmiştir. Aracı etki ölçümünde $\mathrm{X}$ bağımsız değişkeni, $\mathrm{Y}$ bağımlı değişkeni ve $\mathrm{M}$ aracı değişkeni temsil etmektedir. Aracı etkinin belirlenmesi için düşük (BootLLCI) ve yüksek (BootULCI) güven aralıklarının arasında 0 olmaması dikkate alınmaktadır (Hayes, 2013). Ayrıca aracı etki sağlamasının yapılması için Sobel Testi (Baron ve Kennny, 1986) hesaplanmıştır. Hipotezlerin test edilmesi aşamasında üç aşama izlenmiştir. Birinci aşamada bağımsız değişkenin aracı değişkene etkisine, ikinci aşamada bağımsız değişkenin bağımlı değişkene etkisine ve üçüncü aşamada ise bağımsız ve aracı değişkenin birlikte bağımlı değişkene etkisine bakılmıştır. Elde edilen sonuçlar tabloda detaylı olarak gösterilmektedir.

Tablo 6. Aracilik Etkisi

\begin{tabular}{|c|c|c|c|c|c|}
\hline Hipotezler & Aşamalar & Tahmin & SH & $t$ & $\mathrm{p}$ \\
\hline \multirow{4}{*}{ OZG»GVN»IMJ } & $\mathrm{OZG} » \mathrm{IMJ}$ & 813 & ,026 & 39,839 & ,000 \\
\hline & OZG»GVN & 693 & ,031 & 27,476 & ,000 \\
\hline & $\mathrm{OZG»IMJ}$ & ,547 & ,032 & 21,936 & ,000 \\
\hline & GVN»IMJ & ,384 & ,026 & 15,400 & ,000 \\
\hline Aracı Etki & OZG»GVN»IMJ & \multicolumn{3}{|c|}{, $234<, 266<, 305$} & 009 \\
\hline Sobel Testi & ,000 & & & & \\
\hline \multirow{4}{*}{ OZG»GVN»TRC } & OZG»TRC & 695 & ,034 & 27,622 & 000 \\
\hline & OZG»GVN & 693 & ,031 & 27,476 &, 000 \\
\hline & OZG»TRC & 390 & ,042 & 12,438 & 000 \\
\hline & GVN»TRC & 440 & ,035 & 14,052 & ,000 \\
\hline Aracı Etki & OZG»GVN»TRC & \multicolumn{3}{|c|}{, $269<, 305<, 357$} & ,005 \\
\hline Sobel Testi & ,000 & & & & \\
\hline
\end{tabular}

OZG:marka özgünlüğü, GVN: marka güveni, IMJ: marka imajı,TRC: marka tercihi, $\mathrm{p}<0,005$ 
Araştırma kapsamında $\mathrm{H}_{4}$ ve $\mathrm{H}_{5}$ hipotezleri analiz edilerek kabul edildiği görülmüştür. Ayrıca aracllık etkisi Sobel testi (Baron ve Kenny, 1986) ile doğrulanmıştır.

\section{Değerlendirme ve Sonuç}

Bu araştırma, marka özgünlüğünün marka imajı ve marka tercihindeki ilişkisinde marka güveninin aracılık rolünü belirlemeyi amaçlamıştır. Araştırmanın değişkenlerinin ölçülmesine yönelik veriler dayanıklı tüketim mallarından olan beyaz eşya sektörü tüketicilerinden elde edilmiş ve bu veriler genel olarak beyaz eşya kullanan tüketicilerin satın aldıkları ya da kullandıkları beyaz eşya markasına yönelik algılarına dayanarak oluşturulmuştur. $\mathrm{Bu}$ amaçla elde edilen veriler literatür doğrultusunda oluşturulan model üzerinden analizleri yapılarak elde edilmiştir. Araştırmada beyaz eşya sektörü tüketicilerinin seçilme nedenleri arasında, sektörün sürekli olarak güncellenen modelleriyle büyük orandaki tüketiciye hitap etmesi ve bu sektördeki tüketicilerin markalara yönelik algılarının olduğu göz önünde bulundurulmuştur. Veriler ışığında marka özgünlüğünün marka imajı ve marka tercihindeki olası etkilerinin beyaz eşya sektörüne yönelik veriler sunması ve marka yöneticilerine katkı sunması amaçlanmıştır.

Bu amaçla marka özgünlüğünün alt boyutları olan erdem, bağlantı, gerçeklik, estetiklik, kontrtol ve orjinallik ile marka imajı ve marka tercihi ilişkisi incelenerek marka güveninin marka imajı ve marka tercihi üzerindeki aracı etkisi model sşığında incelenmiştir. Bu amaçla 5 ana hipotez ve 12 alt hipotez oluşturulmuştur. Yapılan pilot çalışmadan sonra 816 tüketiciden toplanan veriler doğrultusunda keşfedici faktör analiziyle gözlenen değişkenlerde, araştırma faktörler tespit edilmiş ve daha sonra doğrulayıcı faktör analiziyle ölçeklerin örnekleme uygunluğu belirlenmeye çalışılmış ve nihayetinde ölçme aracının tutarlı ölçüm yaptığını belirlemek amacıyla güvenilirlik analizleri yapılmıştır.

Geçerlilik ve güvenilirlik analizlerinin ardından hipotezlerin testi için yol analizleri gerçekleştirilmiş ve $\mathrm{H} 1_{\mathrm{a}}, \mathrm{H} 1_{\mathrm{b}}, \mathrm{H} 1_{\mathrm{c}}, \mathrm{H} 1_{\mathrm{d}}, \mathrm{H} 1_{\mathrm{e}}, \mathrm{H} 1_{\mathrm{f}}, \mathrm{H} 2_{\mathrm{a}}, \mathrm{H} 2 \mathrm{~b}, \mathrm{H} 2 \mathrm{c}$, $\mathrm{H} 2 \mathrm{~d}, \mathrm{H} 2 \mathrm{e}, \mathrm{H} 2 \mathrm{f}, \mathrm{H} 3$, H4 ve H5 hipotezleri kapsamında marka özgünlüğünün marka imajı ve marka tercihindeki etkisi incelenmiş̧ir. Ayrıca marka güvenini, marka imajı ve marka tercihindeki ilşkisinde, marka güveninin aracılık 
etkisi incelenmiştir. Yapılan analizler sonucunda aşağıdaki sonuçlar bulunmuştur:

- Marka özgünlügünün, marka imajı üzerindeki etkisinde olumlu yönde anlamlı bir etkisi olduğu tespit edilmiştir. Dolayısıyla, H1hipotezi kabul edilmiştir.

- Marka özgünlüğünün alt boyutu olan bağlantı, kontrol ve orjinallik boyutlarının marka imajı üzerindeki etkisinde olumlu yönde anlamlı bir etkisi olduğu ancak; erdem, gerçeklik ve estetiklik boyutlarının ise marka imajını pozitif etkilemediği tespit edilmiştir. Yapılan bu çalışmada bu boyutlar var olan örneklemde kitlesel bir pazar olan beyaz eşya sektöründe desteklenmemiştir. Dolayısıyla, $\mathrm{H} 1$ b, $\mathrm{H} 1_{e}, \mathrm{H} 1_{f}$, hipotezleri desteklenirken $\mathrm{H} 1_{a}, \mathrm{H} 1_{c}, \mathrm{H} 1_{d}$ kabul edilmemiştir.

- Marka özgünlüğünün, marka tercihi üzerindeki etkisinde olumlu yönde anlamlı bir etkisi olduğu tespit edilmiştir. Dolayısıyla, H2 hipotezi kabul edilmiştir.

- Marka özgünlügünün alt boyutu olan erdemlilik ve estetiklik boyutlarının marka tercihi üzerindeki etkisinde olumlu yönde anlamlı bir etkisi olduğu ancak; bağlantı, gerçeklik, kontrol ve orjinallik boyutlarının ise marka imajını pozitif etkilemediği tespit edilmiştir. Yapılan bu çalışmada bağlantı, gerçeklik, kontrol ve orjinallik boyutları var olan örneklemde kitlesel bir pazar olan beyaz eşya sektöründe desteklenmemiştir. Dolayısıyla, $\mathrm{H} 2 \mathrm{a}$, ve $\mathrm{H} 2 \mathrm{~d}$, hipotezleri desteklenirken $\mathrm{H} 2 \mathrm{~b}, \mathrm{H} 2 \mathrm{c}, \mathrm{H} 2 \mathrm{e}$ ve $\mathrm{H} 2 \mathrm{f}$ kabul edilmemiştir.

- Marka imajının marka tercihini pozitif yönde anlamlı etkilediği yapılan analizler sonucunda ortaya koyulmuştur. Dolayısıyla H3, kabul edilmiştir.

- Marka güveninin, marka özgünlügüü ile marka imajı ilişkisinde aracı rolü yapılan analizler sonucunda ortaya koyulmuştur. Dolayısıyla H4, kabul edilmiştir.

- Marka güveninin, marka özgünlüğü ile marka tercihi ilişkisinde aracı rolü yapılan analizler sonucunda ortya koyulmuştur. Dolayısıyla H5, kabul edilmiştir.

Lu vd., (2015) yaptıkları çalışmada özgünlüğü ile marka imajı arasında pozitif bir ilişki olduğunu göstermiştir ( Fritz vd., 2017, s. 330). Tüketim ile ilgili özgünlügü̈n önemi bir çok çalışmada belirtilerek (Grayson ve Martinec, 2004; Hede ve Thyne, 2010; Rose ve Wood, 2005; Beverland vd., 2005; 
Leigh vd., 2006) bu araştırmaların çoğu, tüketicilerin özgünlük algılarının tüketim davranışlarında önemli bir rol oynadığını göstermiştir (Hede vd., 2014, s. 1396). Dwivedi ve McDonald (2018) "marka özgünlüğü" kavramını araştırdıkları çalışmada, marka özgünlüğü ile ürün imajı arasındaki ilişkiyi acıklamaya çalışmışlardır. Bu araştırmada bulunan sonuçlar da bu çalışmalarla tutarlılık göstermektedir.

Marka literatürü, marka tercihinin ana itici güçleri olarak iki bileşeni vurgulamaktadır: marka bilinirliği ve marka imajı (Keller, 1993). Hem Kwon (1990) hem de Keller (2003), olumlu marka imajinın marka tercihine yol açtığını makul bir şekilde belirtmektedir (Alamro, 2010, s. 69). Sharp (2003), marka imajının tüketici karar alma sürecini ve marka seçimini doğrudan etkilediğini belirlemiştir (Maore vd., 2019, s.162-163). Kotler ve Armstrong (1996), marka imajını "belirli bir marka hakkında bir dizi inanç" olarak tanımlamaktadır. Bu inançlar kümesi, müşteriler alternatif markaları değerlendirdiklerinde alıcının karar verme sürecinde önemli bir rol oynamaktadır (Chang ve Liu, 2009, s. 1689). Marka imajının, tüketicilerin zihninde olumlu bir görüşü olduğunda markayı satın almaya teşvik ettiği ve görüş olumsuz olduğunda markayı satın almaktan kaçındığı söylenmektedir (Deneçli, 2014, s. 157-158). Müşteriler için, marka imajı bu markaları satın almak için itici güçtür ( Ratnayake, 2012, s. 53). Myers (2003), marka değerinin marka tercihi üzerindeki etkisini araştırmak için yüksek katılımlı alkolsüz içecek kategorisi üzerinde yapılan çalışmada, marka değeri ile marka tercihi arasında güçlü bir ilişki olduğunu göstermiştir. Özetlemek gerekirse, marka değerinin genellikle marka tercihine önemli bir katkı olduğuna inanilmaktadır (Chang ve Liu, 2009, s. 1691-1692). Marka imajı ile marka tercihini ortaya koyan çalışmalara bakıldığında marka imajının marka tercihini olumlu etkilediği görülmüştür. Dolayısıyla bu çalışmadada literatürle uyumlu bir sonuş elde edilerek hipotez desteklenmiştir.

Daha fazla farkındalık ve daha uygun marka imajı, markaya daha fazla güven sağlar. Bu durumda, marka bilgisi kaynakları olarak kullanıcı deneyimi, ağızdan ağza pazarlama ve reklamcılığın tüketicilerin markaya olan güvenini artırmada önemli etkileri olacağı varsayılmaktadır (Xingyuan vd., 2010, s. 244). Lee ve Tan (2003)'a göre marka imajının genellikle müşterilerin veya tüketicilerin hafızasında tutulan bir marka ve marka çağrışımları hakkındaki algılarla yansıtıldığını ortaya koymaktadır. Bu nedenle, marka imajı, doğası gereği ürün özellik bilgileri için önemli bir destek görevi görebilir 
ve bu da müşterilerin bir markaya olan güvenini artırır (Pavlou vd., 2007). Cretu ve Brodie (2007)'a göre, müşterilerin bir markaya olan güveni ne kadar fazla olursa, o markaya güvenme olasılıkları o kadar artar. Önceki araştırma bulguları, marka imajı ve marka güveni arasında pozitif bir bağlantıyı desteklemektedir (Chinomona, 2016, s. 131). Dolayısıyla bu çalışmadada literatürle uyumlu bir sonuç elde edilerek hipotez desteklenmiştir.

Demirel ve Ylldız $(2015$, s. 83) marka özgünlügüu, marka tercihi, müşteri tatmini ve marka sadakati üzerine yaptıkları çok değişkenli çalışmaları sonucunda, tüketici tercihlerinin değişkenlerden etkilendiğini ifade etmişlerdir. Yine Riefler (2019) yaptığ1 çalışmada marka özgünlüğünün marka tutumu üzerinde olumlu bir etkisi olduğunu gösterme ve algılanan marka özgünlüğü kalite beklentilerini yükseltiğini belirterek, marka özgünlüğünün satın alma niyetlerini arttırdığını ifade etmiştir (Riefler, 2019, s. 3). Ling vd., (2011) çalışması da güven ve satın alma niyetleri arasındaki pozitif ilişkiyi desteklemiştir. Johnson'un (2007) bankacılık alanında yaptığı çalışmada, firmaya duyulan güvenin, firmadan algılanan değer üzerinde önemli ve olumlu bir etkisi olduğunu belirtmişlerdir. Önceki çalışmalar (Bruhn vd., 2012; Schallehn vd., 2014; Moulard vd., 2016; Fritz ve Schoenmueller, 2017 ) marka özgünlügünün marka güveni, algılanan kalite, marka ilişkisi kalitesi ve satın alma niyeti üzerindeki aracı etkilerini ortaya koymuştur (Jian vd., 2019 , s. 5). Chong, Yang ve Wong (2003), güven ve satın alma niyetleri arasındaki değerin aracı rolü olduğunu ortaya koymuşlardır (Lien vd., 2015, s. 3). Güven, süreç ve davranış üzerinde 1 lımlı bir etkiye sahiptir (Liao ve Chen, 2016, s. 2). Dolayısıyla bu çalışmadada literatürle uyumlu bir sonuç elde edilerek hipotez desteklenmiştir. 


\title{
EXTENDED ABSTRACT
}

\section{Mediation Role of Brand Trust in the Relationship of Brand Authenticity in Brand Image and Brand Preference}

\author{
Kazım Dağ - Yakup Durmaz \\ Hasan Kalyoncu University
}

Brand authenticity, which has an increasing importance; It has an important place in terms of survival in today's conditions and strengthening its competitive position and distinguishing itself from other brands. When marketing managers want to create stronger brands; authenticity has become an important dimension of brand identity (Alexander, 2009, p. 551). Authenticity, which refers to the expressions of authentic, real and truthful expressions in a broad sense, has become one of the concepts frequently used in marketing literature in recent years (Arnould and Price, 2000, p. 142). Many firms appear to strive to distinguish their products from other brands. However, it is possible to say that unique brands are more desired by the consumer compared to other brands (Brown et al., 2003, p. 20).

Authenticity is a phenomenon that has become a central component of postmodern branding with growing interest in the past decade. Marketing academics have noticed this demand for authenticity among consumers and luxury wines (Beverland, 2005b, 2006), food (Beer, 2008), tourism (Grayson and Martinec, 2004; Wang, 1999), consumer subcultures (Leigh et al., 2006). ) has done research in many different areas such as reality shows (Rose and Wood, 2005), advertisements (Beverland et al., 2008) and retro brands (Brown et al., 2003). As a result, brands began using this phenomenon as part of their communication strategy to comply with the increasing demand for authenticity. Organizations that can create authenticity within their brands are stated to have the chance to differentiate themselves and gain competitive advantage (Gilmore \& Pine, 2007). This opportunity provides an increased level of interest and relevance in understanding the nature and basic dimensions of brand authenticity (Lindum \& Thomsen, 2019, p. 2). 
Brand authenticity is thought to have a positive effect on brand trust (Beverland, 2005a; Beverland and Farrelly, 2010; Eggers et al., 2013; Gilmore and Pine, 2007; Molleda and Jain, 2013; Schallehn et al., 2014). Fritz, Schoenmueller and Bruhn (2017) show that the brand authenticity may be affected by the determined variables in their studies on the premises and results of brand authenticity. They also stated that they confirmed the positive results on consumer behavior attributed to the concept of authenticity with the marketing literature (Fritz et al., 2017, p. 324). Schallehn, Burmann and Riley (2014) stated in their study that brand authenticity affects brand trust positively (Schallehn et al., 2014, p. 192). Studies carried out on authenticity; reveals that it covers many brand-related concepts such as value, personality, identity, image, positioning, prestige, awareness and commitment, and therefore acts as an umbrella for the brand (Schallehn et al., 2014, p. 194; Spiggle, S., Nguyen , HT and Caravella, M., 2012, p. 968). In the literature review, it was seen that brand authenticity was associated with brand preference, brand loyalty, brand loyalty and brand trust (Demirel and Y1ldiz, 2015; Eggers et al., 2013; Assiouras, 2015).

Kotler and Armstrong (1996) define brand image as "a series of beliefs about a particular brand" (Chang and Liu, 2009, 1689). According to Keller (1993), brand image is a combination of brand affiliates, including features (product-related and non-product-related), benefits (functional, symbolic, experiential) and attitudes (Cho et al., 2014, p. 30).

The concept of choice in marketing means desirability or choice among alternatives (Oliver and Swan, 1989). Also, brand preference takes into account the rational and irrational aspects of consumer behavior (Ebrahim et al., 2016, p. 1230). Zajonc and Markus (1982, p. 128) stated that "a preference is a behavioral tendency that shows itself too much about how the individual treats him, not what he thinks or says about the object." Brand trust is the desire of the average consumer to trust the ability of the brand to perform its specified function (Ha and Perks, 2005, p. 443). Brand trust is a consumer judgment about the reliability of a particular brand (Azizi, 2014, p. 22).

The purpose of this research is to determine the brand authenticity, which is an element that will ensure survival in today's financial crises; determining the effect on brand image and brand preference, as well as revealing whether brand trust has an intermediary effect on brand image and 
brand preference. In the light of the above findings, the following hypotheses have been developed.

- H1. Brand authenticity affects brand image positively.

- H1a Virtue, a sub-dimension of brand authenticity, positively affects the brand image.

- H1b As a sub-dimension of brand authenticity, the connection positively affects the brand image.

- H1c The sub-dimension of brand authenticity, reality affects the brand image positively.

- H1d Aesthetics, which is the sub-dimension of brand authenticity, affects the brand image positively.

- H1e Control, which is the sub-dimension of brand authenticity, affects the brand image positively.

- H1f Originality, which is the sub-dimension of brand authenticity, affects the brand image positively.

- H2. Brand authenticity affects brand preference positively.

- H2a Virtue, a sub-dimension of brand authenticity, positively affects brand preference.

- H2b The link, which is the sub-dimension of brand authenticity, positively affects brand preference.

- H2c The reality, which is the sub-dimension of brand authenticity, affects brand preference positively.

- H2d Aesthetics, which is the sub-dimension of brand authenticity, positively affects brand preference.

- H2e Control, which is the sub-dimension of brand authenticity, affects brand preference positively.

- H2f Originality, which is the sub-dimension of brand authenticity, affects brand preference positively.

- H3. Brand image affects brand preference positively.

- H4. Brand trust has an intermediary role in the relationship between brand authenticity and brand image.

- H5. Brand trust has an intermediary role in the relationship between brand authenticity and brand preference.

In the research, questionnaire form was used as data collection technique. With the questionnaire developed in this context, questions created 
by combining the brand authenticity, brand image, brand preference and brand trust questions and personal information form were used.

In this research, the brand authenticity scale developed by Tran and Keng (2018) was used. The scale consists of six dimension and 18 items. The overall reliability level of brand authenticity was determined as 0.94 . Brand Image The scale adapted from the study by Salinas and Perez (2009) was used. The scale consists of one dimension and 8 items. It has been determined that the reliability level of the brand image is 0.94 . The brand preference scale used by Chang and Liu (2009) in their study for the service sector was used. Scale; It consists of one dimension and 4 items. The reliability level of the brand preference was found to be 0,90 . The brand trust scale developed by Nicole Koschate-Fischer and Susanne Gartner (2015) was used. It has been determined that the reliability level of brand trust is 0,90 .

As a result of the analyzes, the following results were found: It has been determined that brand authenticity has a positive meaningful effect on the brand image. Hence, the H1 hypothesis was accepted. However, the subdimension of brand authenticity, connection, control and originality have a positive effect on the effect of the brand image; It was determined that the dimensions of virtue, reality and aesthetics did not affect the brand image positively. In this study, these dimensions were not supported in the white goods sector, which is a mass market in the existing sample. Therefore, while H1b, H1e, H1f, hypotheses are supported, H1a, H1c, H1d were not accepted. It has been determined that the brand authenticity has a positive effect on the effect on the brand preference. Hence, the $\mathrm{H} 2$ hypothesis was accepted. However, the virtue and aesthetics dimensions, which are the subdimensions of brand authenticity, have a positive effect on the effect of brand preference. It was determined that the dimensions of connection, reality, control and originality did not affect the brand image positively. In this study, connection, reality, control and originality dimensions were not supported in the white goods sector, which is a mass market in the sample. Therefore, H2b, H2c, H2e and H2f were not accepted, while the hypotheses $\mathrm{H} 2 \mathrm{a}$, and $\mathrm{H} 2 \mathrm{~d}$ were supported. It has been revealed as a result of the analysis that brand image has a positive and significant effect on brand preference. $\mathrm{H} 3$ is therefore accepted. Brand trust has been revealed as a result of the analyzes performed as an intermediary role in the relationship between brand authenticity and brand image. $\mathrm{H} 4$ is therefore accepted. As a result of 
the analyzes carried out as an intermediary role in the relationship between brand trust and brand preference, brand preference was placed. $\mathrm{H} 5$ is therefore accepted.

Lu et al. (2015) showed a positive relationship between their authenticity and brand image in their study (Fritz et al., 2017, p. 330). Both Kwon (1990) and Keller (2003) reasonably state that the positive brand image leads to brand preference (Alamro, 2010, p. 69). Sharp (2003) found that brand image directly affects consumer decision making and brand selection (Maore et al., 2019, pp. 162-163). Therefore, in this study, a result compatible with the literature was obtained.

\section{Kaynakça / References}

Aaker, D. A. (1996). Building strong brands. New York, NY: The Free Press/Simon and Schuster.

Arnould, E.,J. and Price, L., L. (2000). Authenticating acts and authoritative performances: questing for self and community. In: Ratneshwar, S., Mick, D.G. and Huffman, C. (Eds.). The Why of Consumption. (p. 140-163). New York:Routledge.

Arnold, D. (1992). The handbook of brand management. Reading: Addison Wesley.

Arthur W. Page Society. (2007). The authentic enterprise:An Arthur W. Page Society report. New York: Arthur W Page Society.

Aksoy, H. (2018). Sponsor Marka kimlik uyumunun marka imaj transferi üzerine etkisi: çoklu fuar sponsorluğunun analizi. Gaziantep UniversityJournal of Social Sciences, 17(4), 1456-1473,

Assiouras, I., Liapati, G., Kouletsis, G., and Koniordos, M. (2015). The impact of brand authenticity on brand attachment in the food industry. British FoodJournal, 117(2), 538-552. https://doi.org/10.1108/BFJ-03-2014-0095

Alexander, N. (2009). Brand authentication: creating and maintaining brand auras. European Journal of Marketing, 43(3/4), 551-562. doi:10.1108/03090560910935578

Alamro, A., Salameh (2010). Branding and brand preference in the mobile phone service industry. Doctora PhD. Prifysgol Bangor University

Baron, R. M., and Kenny, D. A. (1986). The Moderator-Mediator Variable Distinction in Social Psychological Research: Conceptual, Strategic and Statistical Considerations. Journal of Personality and Social Psychology, 51(6), 1173-1182.

Ballantyne, R., Warren, A. ve Nobbs, K. (2006). The evolution of brand choice", Journal of Brand Management, 13(4/5), 339-352. 
Beer, S. (2008). Authenticity and food experience - commercial and academic perspectives. Journal of Foodservice, 19(3), 153-163.

Beverland, M.B., Lindgreen, A. and Vink, M.W. (2008). Projecting authenticity through advertising: Consumer judgements of advertisers' claims. Journalof Advertising,37 (1), 5-15.

Beverland,B.,M. ve Francis J. Farrelly (2010). The quest for authenticity in consumption: consumers' purposive choice of authentic cues to shape experienced outcomes. Journal of Consumer Research, 36(5)

Beverland., B., M. (2005a).Crafting brand authenticity: The case of luxury wines.Journal of Management Studies 42(5), 0022-2380

Brown, S., Kozinets, R. V., ve Sherry, J. F. (2003). Teaching old brands newtricks: Retro branding and the revival of brand meaning. Journal of Marketing, 67(3), 19-33. doi:10.1509/jmkg.67.3.19.18657

Bruhn, M., Schoenmüller, V., Schäfer, D. ve Heinrich D. (2012). Brand authent city: Towards a deeper understanding of its conceptualization and measurement.Advances in ConsumerResearch Associationfor Consumer Research, 40, 567576.

Beverland, M. (2005a). Crafting brand authenticity: The case of luxury wines. Journal of Management Studies, 42(5), 1003-1029.

Beverland, M. B. (2006). The 'real thing': Branding authenticity in the luxury wine trade. Journal of Business Research, 59(2), 251-258. doi:10.1016/j.jbusres.2005.04.007

Busser, J.A, ve Shulga, L.V. (2019). Involvement in consumer-generated advertising: Effects of organizational transparency and brand authenticity on loyalty and trust", International Journalof Contemporary Hospitality Management, https://doi.org/10.1108/IJCHM-10-2017-0685

Chen, H., Bernard, S., ve Rahman, I. (2018). Greenwashing in hotels: A structural model of trustand behavioral intentions. Journal of CleanerProduction. doi:10.1016/j.jclepro.2018.09.168

Cretu, A. E., ve Brodie, R. J. (2007). The influence of brand image and company reputationwhere manufacturers market to small firms: A customer value perspective. IndustrialMarketing Management, 36, 230-240.

Cho, E., Fiore, A., M.(2015) Conceptualization of a holistic brand image measurefor fashion-related brands.Journal of Consumer Marketing, 32(4), 255-265, https://doi.org/10.1108//CM-07-2014-1063 
Cho, E., Fiore, A.,M. ve Russell, D.,W. (2014). Validation of a fashion brand mage scale capturing cognitive, sensory, and affective associations: Testing its role in an extended brand equity model. Psychology and Marketing,32(1), 28-48 DOI: $10.1002 /$ mar.20762

Chomvilailuk, R., and Butcher, K. (2010). Enhancing brand preference through corporate social responsibility initiatives in the Thai banking sector. AsiaPacific Journal of Marketing and Logistics, 22(3),397-418. doi:10.1108/13555851011062296

Chatterjee, S. C., and A. Chaudhuri. 2005. Are trusted brands important. Marketing Management Journal, 15(1), 1-16.

Chinomona, R. (2016). Brand communication, brand image and brand trust as antecedents of brand loyalty in Gauteng Province of South Africa. AfricanJournal of Economic and Management Studies, 7(1), 124-139. doi:10.1108/ajems-03-20130031

Cappannelli, G., ve Cappannelli, S. C. (2004). Authenticity: Simple strategies for greater meaningand purpose at work and at home. Cincinnati, $\mathrm{OH}$ : Emmis Books.

Chaudhuri, A., ve Holbrook, M. (2001). The chain of effects from brand trust and brand affect to brand performance: The role of brand loyalty. Journal ofMarketing, 65(2), 81-93. doi:10.1509/jmkg.65.2.81.18255

Chang, H.H. ve Liu, Y.M. (2009). The impact of brand equity on brand preference and purchase intention in the services industries. The ServiceIndustries Journal. 29 (12), 1687-1706. DOI: 10.1080/02642060902793557

Chong, B., Yang, Z., and Wong, M. (2003). Asymmetrical impact of trustworthiness attributes on trust, perceived value and purchase intention: A conceptual framework for cross-cultural study on consumer perception of online auction. In ICEC '03 Proceedings of the 5thInternational Conference on Electronic Commerce, (p. 213-219). New York, NY: ACM Press.

Chhabra, D., and Kim, E. G. (2018). Brand authenticity of heritage festivals. Annals of TourismResearch, 68, 55-57. doi:10.1016/j.annals.2017.11.007

Chhabra, D. (2010). Branding authenticity. Tourism Analysis, 15(6), 735-740.

Coary, S. P. (2013). Scale construction and effects of brand authenticity. University ofSouthern California, ProQuest Dissertations Publishing, 3598187.

Çavuşoğlu, S. ve Durmaz, Y.(2020). Deneyimsel pazarlama ve yeşil davranı̧̧.(1.Basım). İstanbul: Hiper Yayın.

Delgado-Ballester, E. (2004). Applicability of a brand trust scale across product categories. European Journal of Marketing, 38(5/6), 573-592. doi:10.1108/03090560410529222 
Demirağ, B. ve Durmaz, Y.(2020). Marka yönetimi (Uygulamalı). 1.Baskı. Hiper Yayınlari. İstanbul.

Demirağ, B. ve Çavuşoğlu, S (2019). Marka imajının tutumsal marka sadakati üzerindeki etkisininincelenmesi: Bingöl otelleri örneği. To $\mathcal{E}$ Re,1(1), 15-22

Demirel, E,Ü. ve Yıldız, E. (2015). Marka özgünlüğünün marka tercihi, müşteri tatmini ve marka sadakati üzerindeki etkileri: Bilgisayar markaları üzerine bir araştırma. Marmara Üniversitesi Öneri Dergisi, 11(44), 83-100.

Deneçli, S. (2014), Marka ve maskotlar: Imaj üretimi, Ed. G. Ilıcak Aydınalp, Nobel Yayınları Ankara.

Diker, E , ve Özüpek, M . (2013). İletişim fakültesi öğrencilerinin cep telefonumarkalarına yönelik imaj algısı: Nokia ve Samsung örneği. HumanitiesSciences, 8(1) ,100-120.

Dobni, D.I ve Zinkhan, G.M. (1990). In search of brand image: a foundation analysis", in Goldberg, M.E., Gorn, G. and Pollay, R.W. (Eds), Advances in Consumer Research, Association for Consumer Research, Provo, T.

Dolich, I. J. (1969). Congruence relationships between self-images and product Brands. Journal of Marketing Research, 6, 80-84.

Durmaz, Y. Dağ, K. (2018). Marka özgünlüğünün marka sadakati üzerindeki etkileri: cep telefonu markaları üzerine bir araştırma. AkademikAraştırmalar ve Çalışmalar Dergisi.10(19), 489-501 DOI: 10.20990/kilisiibfakademik.406708

Durmaz, Y., Çavuşoğlu, S., ve Özer, Ö. (2018). The effect of brand ımage and brand benefit on customer loyalty: The case of Turkey. International Journal of Academic Research in Businessand Social Sciences, 8(5), 528-540. DOI: 10.6007/IJARBSS/v8-i5/4140

Dülek, B. ve Saydan, R. (2019). The impact of social media advertisement awareness on brand awareness, brand image, brand attitude and brand loyalty: A research on university students. International Journal of Contemporary Economics and Administrative Sciences, 9(2), 470-494. http://doi.org/10.5281/zenodo.3596116

Dwivedi, A. ve McDonald. R. (2018). "Building brand authenticity in fast-moving consumer goods via consumer perceptions of brand marketing communications", European Journal of Marketing, 52(7/8), 1387-1411, https://doi.org/10.1108/EJM-11-2016-0665

Eggers, F., O'Dwyer, M., Kraus, S., Vallaster, C. ve Guldenberg, S. (2013), "The impact of brand authenticity on brand trust and sme growth: a CEO perspective", Journal of World Business, 48(3), 340-348. 
Ebrahim, R., Ghoneim, A., Irani, Z., ve Fan, Y. (2016). A brand preference and repurchase intention model: the role of consumer experience, Journal of Marketing Management, 32(13-14), 1230-1259, DOI: 10.1080/0267257X.2016.1150322

Ebrahim, R., S. (2013).A study of brand preference : an experiential view. PhD Thesis. Brunel University

Fishbein, M. (1965). A consideration of beliefs, attitudes, and their relationships. In J. Seteiner, ve M. Fishbein (Eds.), Current studies in social psychology. New York: Holt, Reinhart and Winston.

Fritz, K., Schoenmueller, V and Bruhn, M. (2017). Authenticity in branding:Exploring antecedents and consequences of brand authenticity. EuropeanJournal of Marketing, 51(2), 324-348. https://doi.org/10.1108/ejm-10-2014-0633

Folse J. A. G., Burton S. and Netemeyer R.G. (2013). Defending brands: Effects of alignment of spokescharacter personality traits and corporate transgressions on brand trust and attitudes.Journal of Advertising, 42(4), 331-342, DOI: 10.1080/00913367.2013.795124

Grayson, K., and Martinec, R. (2004). Consumer perceptions of iconicity and indexicality and their influence on assessments of authentic market offerings, Journal of Consumer Research, 31(2), 296-312. https://doi.org/10.1086/422109

Gilmore, J. H., ve Pine, B. J. (2007). Authenticity: What consumers really want. Boston: Harvard Business School Press.

Gürbüz, S. ve Şahin, F. (2016). Sosyal bilimlerde araştrma yöntemleri felsefe-yöntem- analiz. (3. Baskı). Ankara: Seçkin Yayınevi.

Ha H-Y. and Perks H. (2005). Effects of consumer perceptions of brand experience on the web:Brand familiarity, satisfaction and brand trust. Journal of Consumer Behaviour 4(6), 438-452

Hede, A.-M. and Thyne, M. (2010). A journey to the authentic: museum visitorsand their negotiation of the inauthentic.Journal of Marketing Management, 26(7/8), 686-705.

Harris, L. C., Goode, M. M., 2010. Online servicescapes, trust, and purchase intentions. J. Serv. Mkt. 24(3), 230-243.

Han, S. H., Nguyen B., ve Lee T. J. (2015). Consumer-based chain restaurant brand equity, brand reputation, and brand trust. International Journal ofHospitality Management.50, 84-93. http://dx.doi.org/10.1016/j.jighm.2015.06.010

Hair, J. F., Black, W., Anderson, R., Babin, B. R. ve Tahtam, R. L. (2006). Multivariate data analysis with readings. London: Mcmillan Book Company. 
He, H., Harris, L. C., Wang, W., and Haider, K. (2016). Brand identity and online selfcustomisation usefulness perception. Journal of Marketing Management,32(1314), 1308-1332. doi:10.1080/0267257x.2016.1170720

Hellier, P.K., Geursen, G.M., Carr, R.A., ve Rickard, J.A. (2003). Customer repurchase intention: A general structural equation model. EuropeanJournal of Marketing, 37(11/12), 1762-1800.

Heider, F. (1958). The psychology of interpersonal relations. Lawrence Erlbaum Associates, New York, NY.

Jian, Y., Zhou, Z., and Zhou, N. (2019). Brand cultural symbolism, brand authenticity, andConsumer well-being: the moderating role of culturalinvolvement. Journal of Product EBrandManagement. doi:10.1108/jpbm-08-2018-1981

Johnson, D. S. (2007). Achieving customer value from electronic channels through identity commitment, calculative commitment, and trust intechnology. Journal of Interactive Marketing, 21(4), 2-22.

Keller, K. L. (1993). Conceptualizing, measuring, and managing customer-based brand equity.Journal of Marketing, 1-22. doi: 10.2307/1252054

Keller, K. L., (2003). Strategic brand management: building, measuring, and managing brand equity. 2nd edition, Upper Saddle River, NJ: Pearson Education

Ketron, S. (2016). Consumer cynicism and perceived deception in vanity sizing: The moderatingrole of retailer (dis)honesty. Journal of Retailing andConsumer Services, 33, 33-42.

Kotler, P., and Armstrong, G. (1996). Principles of marketing. New Jersey: Prentice-Hall.

Koschate-Fischer, N., and Gartner, S. (2015). Brand Trust: Scale Development and Validation. Schmalenbach Business Review, 67(2), 171-195. doi:10.1007/bf03396873

Kwon, Y., (1990). Brand name awareness and image perception of women's daytime apparel. Perceptual and Motor Skills, 71, 743-52.

Lassoued, R., ve Hobbs, J.E. (2015). Consumer confidence in credence attributes: The role of brand trust. Food Policyhttp:// dx.doi.org/10.1016/j.foodpol.2014.12.003

Lee D., Moon J., Kim Y.J., ve Yi M.Y.(2014). Antecedents and consequences of mobile phone usability: Linking simplicity and interactivity to satisfaction, trust, and brand loyalty, Information and Management http://dx.doi.org/10.1016/j.im.2014.12.001

Lee, K.S. and Tan, S.J. (2003). E-retailing versus physical retailing: A theoretical model and empirical test of consumer choice. Journal of Business Research, 56(11), 877885 
Liao and Мa. (2009).Conceptualizing consumer need for product authenticity. International Journal of Business and Information.4(1).

Liao S-H. and Chen Y-J. (2016). A rough set-based association rule approach implemented on a brand trust evaluation model.Journal of Experimental \& Theoretical Artificial Intelligence, DOI: 10.1080/0952813X.2016.1264089

Lien, C.-H., Wen M-J., Huang L-C., ve Wu K-L.(2015). Online hotel booking: The effects of brand image, price, trust and value on purchase intentions, AsiaPacific Management Review http://dx.doi.org/10.1016/j.apmrv.

Ling, K. C., bin Daud, D., Piew, T. H., Keoy, K. H., veHassan, P. (2011). Perceived risk, perceived technology, online trust for the online purchase intention in Malaysia. International Journal of Business and Management, 6(6), 167-182.

Lindum, M., H., ve Thomsen, P., W. (2019). The nature of brand authenticity a case study of soundboks from a multiple-stakeholder perspective. MSc Brand andCommunications Management Master's Thesis.

Lu, A. C. C., Gursoy, D., ve Lu, C. Y. (2015). Authenticity perceptions, brand equity and brand choice intention: The case of ethnic restaurants. International Journal of Hospitality Management, 50, 36-45. doi:10.1016/j.ijhm.2015.07.008

Luffarelli, J., Mukesh, M., ve Mahmood, A. (2019). Let the Logo Do the Talking: The Influence of Logo Descriptiveness on Brand Equity. Journal ofMarketing Research, doi:10.1177/0022243719845000

Mabkhot H. A., Shaari H., Salleh S. (2017). The influence of brand image andbrand personality on brand loyalty, mediating by brand trust: An empirical study. Jurnal Pengurusan50(2017) 71-82 https://doi.org/10.17576/pengurusan-201750-07

Maore S., Munyoki J., Kinoti M., Owino J. (2019). Brand management practices, corporate image, customer characteristics and satisfaction among University Students in Kenya. European Scientific Journal December 2019 15(34) ISSN:1857-7881 (Print) e-ISSN 1857-7431. Doi:10.19044/esj.2019.v15n34p161

Menidjel C., Benhabib A., ve Bilgihan A. (2017). "Examining the moderating role of personality traits in the relationship between brand trust and brand loyalty", Journal of Product \& Brand Management, https://doi.org/10.1108/JPBM-05-20161163

Myers, C.A. (2003). Managing brand equity: A look at the impact of attributes. Journal of Product \& Brand Management,12(1), 39-51. 
Michaelidou, N., Micevski, M., Cadogan J., W.(2015). An evaluation of nonprofit brand image: Towards a beter conceptualization and measurement. Journal of Business Research,68 (2015),

$1657-1666$. http://dx.doi.org/10.1016/j.jbusres.2015.03.024

Munoz, C.L., Wood, N.T.; and Solomon, M.R. (2006). Real or blarney? A cross-cultural investigation of the perceived authenticity of Irish pubs, Journal ofConsumer Behaviour 5, 222-234.

Molleda, J.-C., and Jain, R. (2013). Testing a perceived authenticity index with triangulation research: The case of Xcaret in Mexico. International Journalof Strategic Communication, 7(1), 1-20.

Morhart, F., Malär, L., Guèvremont, A., Girardin, F., ve Grohmann B. (2015). Brand authenticity: An integrative framework and measurement scale. Journal of $\begin{array}{llll}\text { Consumer Psychology 200-218. } & \text { 25, 2, }\end{array}$ http://dx.doi.org/10.1016/j.jcps.2014.11.006

Mohajerani, P., ve Miremadi, A. (2012). Customer satisfaction modeling in hotel industry: A case study of Kish Island in Iran. International. Journal of Marketing Studies, 4(3), 134- 152.

Napoli, J., Dickinson, S.J., Beverland, M.B. veFarrelly, F. (2014). Measuring consumerbased brand authenticity," Journal of Business Research, 67(6), 1090-1098. doi:10.1016/j.jbusres.2013.06.001

Napoli, J, Dickinson-Delaporte, S., ve Beverland, M (2016). The brand Authenticity continuum: Strategic approaches for building value. Journal of Marketing Management, 32(13-14), 1201-1229. https://doi.org/10.1080/0267257x.2016.1145722

Oliver, R.L. ve Swan, J.E. (1989). Consumer Perceptions of Interpersonal Equity and Satisfaction in Transactions: A Field Survey Approach, Journal ofMarketing, 53, 21-35.

Oh, H., Prado, P. H. M., Korelo, J. C., and Frizzo, F. (2019). The effect of brand authenticity on consumer-brand relationships. Journal of Product $\mathcal{E}$ BrandManagement. doi:10.1108/jpbm-09-2017-1567

Pavlou, P. A., Liang, H. ve Xue, Y. (2007). Understanding and mitigating uncertainty in onlineexchange relationships: A principal-agent perspective.MIS Quarterly, 31(1), 105-136.

Pattuglia S.,ve Mingione M. (2017). Towards a new understanding of brand authenticity: seeing through the lens of millennials. sinergie italian journal of management, 35(103).DOI: https://doi.org/10.7433/s103.2017.03

Peterson, R.A. (2005). In search of authenticity. Journal of Management Studies, 42(5), 1083-98. 
Portal, S. Russell Abratt, R., ve Bendixen, M. (2018): The role of brand authenticity in developing brand trust.Journal of Strategic Marketing, DOI: 10.1080/0965254X.2018.1466828

Ratnayake, N. (2012) The Predictive validity of brand-related autobiographical memories on brand commitment. $\mathrm{PhD}$ thesis. Coventry: Coventry University

Rajavi, K., Kushwaha, T., and Steenkamp, J.-B. E. M. (2019). In brands we trust? a multi-category, multi-country investigation of sensitivity of consumers'trust in brands to marketing-mix activities. Journal of Consumer Research. doi:10.1093/jcr/ucz026

Riefler, P. (2019). Local versus global food consumption: the role of brand authenticity. Journal of Consumer Marketing Emerald Publishing Limited DOI 10.1108/JCM02-2019-3086]

Riezebos, R. K. (2003). Brand management-a theoretical and practical approach. Harlow: Pearson Education Limited.

Rose, R.L., ve Wood, S.L. (2005). Paradox and the consumption of authenticity through reality television, Journal of Consumer Research, 32(2), 284-296.

Salinas, E., M., ve Pérez J.,M.,P. (2009). Modeling the brand extensions' influence on brand image. Journal of Business Research, 62, 50-60. doi:10.1016/j.jbusres.2008.01.006

Saleem, H., ve Raja, N. S. (2014). The impact of service quality on customer satisfaction customer loyalty. Middle-East Journal of Scientific Research, 19(5),706-711.

Sarıçiçek, R. , Çokay Çopuroğlu, F. ve Korkmaz, I . (2017).Brand 1dentity and brand Image of consumers in retro marketing context: A research on GAUN Academicians. Gaziantep University Journal of Social Sciences,16 (2), 345-358. DOI: 10.21547/jss.300703

Surprenant, C. F., and M. R. Solomon. (1987). Predictability and personalization in the service encounter. The Journal of Marketing 51, 86-96.

Schallehn, M., Burmann, C., and Riley, N. (2014). Brand authenticity: Model development and empirical testing. Journal of Product \& Brand Management,23(3), 192199. https://doi.org/10.1108/JPBM-06-2013-0339

Spiggle, S., H. T. Nguyen, ve M. Caravella. (2012). More than fit: Brand extension authenticity. Journal of Marketing Research 49 (6), 967-983.

Tran, V.-D., and Keng, C.-J. (2018). The brand authenticity scale: Development and Validation. Contemporary Management Research, 14(4), 277-291. https://doi.org/10.7903/cmr.18581 
Uzunkaya T. (2017). Marka iletişiminin marka güvenine etkisi, Bilgisayar markaları üzerine bir araştırma. $\quad B U J S S, 10(2), \quad 33-40 \quad$ DOI: http://dx.doi.org/10.18221/bujss.332360

Uztuğ, F.(2003).Markan kadar konuş,4. Basım.İstanbul: Kapital Yayınevi, Wang, N. (1999). Rethinking authenticity in tourism experience, 26(2), 349-370.

Wang, E. S.-T. (2015). Effect of food service-brand equity on consumer-perceived food value, physical risk, and brand preference. British Food Journal, 117(2),553564. doi:10.1108/bfi-09-2013-0260

Wang, Ya-Hui veTsai, Cing-Fen.(2014). The relationship between brand image and purchase intention: Evidence from award winning mutual funds. The International Journal of Business and Finance Research, 8(2),27-40.

Wymer, W., ve Akbar, M. M. (2017). Brand authenticity, its conceptualization, and its relevance to nonprofit marketing. International Review on Publicand Nonprofit Marketing, 14(3), 359-374. doi:10.1007/s12208-017-0177-z

Xingyuan W., Li F., ve Wei Y. (2010) How do they really help? An empirical study of the role of different information sources in building brand trust. Journal of Global Marketing, 23(3), 243-252, DOI: 10.1080/08911762.2010.487425

Yakut, E . (2018). Examination of product recalls in terms of attribution theory in themarketing context: A qualitative meta-analysis. Yönetim ve Ekonomi: Celal Bayar Üniversitesi İktisadi ve İdari Bilimler FakültesiDergisi , 25(2) , 351-367 . DOI: 10.18657/yonveek.350583

Yannopoulou N., Koronis E., ve Elliott R. (2011). Media amplification of a brand crisis and its affect on brand trust, Journal of Marketing Management, 27(5-6), 530-546, DOI:10.1080/0267257X.2010.498141

Zajonc, R.B. and Markus, H. (1982). Affective and cognitive factors in preferences, Journal of Consumer Research, 9(2), 123-131.

\section{Kaynakça Bilgisi / Citation Information}

Dağ, K. ve Durmaz, Y.(2020).Marka özgünlügünün marka imajı ve marka tercihindeki ilişkisinde marka güveninin aracılık rolü. OPUSUluslararası Toplum Araştırmaları Dergisi, 16(32), 4840-4874.DOI: 10.26466/opus.741062 